\title{
PENGARUH ADMINISTRASI PENDIDIKAN DAN SUPERVISI AKADEMIK TERHADAP KINERJA GURU PADA MAN 1 BINTAN KEPULAUAN RIAU
}

\author{
Saripuddin $^{* 1}$, Lias Hasibuan ${ }^{2}$, Kasful Anwar Us ${ }^{3}$ \\ ${ }^{1}$ MAN 1 Bintan Kepulauan Riau \\ ${ }^{2,3}$ Program Pascasarjana UIN Sultan Thaha Syaifuddin Jambi \\ e-mail: ${ }^{* 1}$ syarifsaripuddin417@gmail.com, ${ }^{2}$ lhas10@yahoo.co.id, ${ }^{3}$ kasfulanwarus@gmail.com
}

\begin{abstract}
Abstrak
Penelitian ini bertujuan untuk mengetahui dan menganalisis: pengaruh administrasi pendidikan dan supervisi akademik terhadap kinerja guru di MAN 1 Bintan Kepulauan Riau. Pendekatan penelitian ini menggunakan penelitian survei. Waktu penelitian dilaksanakan mulai bulan Mei 2021. Populasi penelitian adalah 30 orang guru yang mengajar di MAN 1 Bintang Kijang Kepulauan Riau. Pemilihan sampel dalam penelitian ini dilakukan dengan menggunakan metode sensus dimana populasi bertindak sebagai sampel. Hasil penelitian menunjukkan bahwa: 1) Tidak ada pengaruh positif dan signifikan administrasi pendidikan secara individual (parsial) terhadap kinerja guru di MAN 1 Bintang Kijang Kepulauan Riau. 2) Terdapat pengaruh yang positif dan signifikan supervisi akademik individu (parsial) terhadap kinerja guru di MAN 1 Bintang Kijang Kepulauan Riau. 3) Ada pengaruh simultan (simultan) administrasi pendidikan dan supervisi akademik terhadap kinerja guru di MAN 1 Bintang Kijang Kepulauan Riau. Berdasarkan hasil penelitian diperoleh koefisien determinasi (R2) sebesar 0,534 atau $(53,4 \%)$. Hal ini menunjukkan bahwa 53,4\% kinerja guru dipengaruhi oleh administrasi pendidikan dan supervisi akademik. Sedangkan 46,6\% dipengaruhi oleh variabel lain yang tidak termasuk dalam model penelitian ini.
\end{abstract}

Kata kunci: administrasi pendidikan, supervisi akademik dan kinerja guru

\begin{abstract}
This study aims to determine and analyze: the effect of educational administration and academic supervision on teacher performance at MAN 1 BintanRiau Islands. This research approach uses survey research. The time of the study was carried out starting in May 2021. The research population was 30 teachers who taught at MAN 1 Bintang Kijang, Riau Islands. The sample selection in this study was carried out using the census method where the population acted as a sample. The results showed that: 1) There was no positive and significant effect of education administration individually (partial) on teacher performance at MAN 1 Bintang Kijang, Riau Islands. 2) There is a positive and significant effect of individual (partial) academic supervision on teacher performance at MAN 1 Bintang Kijang, Riau Islands. 3) There is a simultaneous (simultaneous) effect of education administration and academic supervision on teacher performance at MAN 1 Bintang Kijang, Riau Islands. Based on the results of the study, the coefficient of determination (R2) was 0.534 or (53.4\%). This shows that $53.4 \%$ of teacher performance is influenced by education administration and academic supervision. While $46.6 \%$ is influenced by other variables that are not included in this research model.
\end{abstract}

Keywords: education administration, academic supervision and teacher performance

\section{PENDAHULUAN}

Tenaga pendidik dalam hal ini guru adalah bagian komponen dunia pendidikan. Dan Makna guru adalah orang yang bertanggungjawab terhadap hak siswa terhadap pembelajaran, baik sifatnya individual maupun kelompok, dalam lingkungan sekolah maupun di lingkungan luar sekolah (Syaiful Bahri Djamarah, 2010:26). Dengan demikian kinerja seorang tenaga pendidik (guru) adalah kemampuan yang ditunjukkan 
oleh guru dalam melaksanakan tugas atau pekerjaannya (Tutik Rachmawati dan Daryanto, 2013:16).Artinya, adanya kinerja guru yang baik maka proses pembelajaran akan menjadi maksimal. Sedangkan kinerja guru menurut Wahyuudi (2012: 86) diartikan sebagai experience, keahlian, integritas serta pemanfaatan waktu seorang pendidik dalam mengemban amanah untuk mencapai hasil berdasarkan tujuan ynag ingin dicapai oleh lembaga pendidikan. Seorang pendidik dikatakan memiliki kinerja yang baik dan optimal manakala tujuan pembelajaran sudah terlaksana sesuai dengan tujuan yang telah ditetapkan bersama. Selain itu, pendidikan yang efektif secara tidak langsung dipengaruhi oleh kinerja guru yang baik pula sebagaimana dikemukakan oleh Husdart (2013: 55), bahwa prestasi akademik pendidik akan mempengaruhi peningkatan kedisiplinan, karakter, sikap dan capaian studi peserta didik demi tercapainya proses pendidikan yang efektif.

Madrasah sebagai tempat atau wadah guru dalam melaksanakan tugasnya sebagai tenaga pendidik mempunyai tugas dan tanggungjawab dalam merencanakan PBM, melaksanakan PBM dan mengevaluasi PBM. Madrasah adalah merupakan instansi pendidikan dibawah naungan Kementerian Agama yang terpadu antara elemen yang satu dengan elemen lainnya. Administarsi pendidikan merupakan salah satu elemen yang sangat urgen dan menentukan dalam sebuah institusi pendidikan. Adminsitrasi pendidikan memainkan peran penting dalam memastikan pencapaian misi madrasah dan kelancaran fungsi pendirian madrasah. Banyak orang yang memandang administrasi pendidikan hanya sebagai tugas-tugas administratif seperti mengkoordinir surat menyurat, mencatat penerimaan, mengatur penyimpanan, menyiapkan dokumen, mengeluarkan barang, dan sebagainya. Sejauh kegiatan administrasi berjalan, ini tidak terlalu salah karena tugas-tugas seperti itu selalu terlibat mencakup fungsi-fungsi tersebut. Administrasi bukan sekedar pencatatan kegiatan melainkan juga bermakna kelembagaan, fungsional serta upaya maupun metode untuk mewujudkan fungsi edukasi.

Menurut pandangan Engkoswara (2011) adminsitrasi Pendidikan adalah ilmu yang menjelaskan tentang pengelolaan sumber daya manusia termasuk didalamnya kurikulum dan fasilitas, terciptanya situasi dan kondisi yang nyaman serta menyenangkan dalam rangka mewujudkan fungsi edukasi secara maksimal dan efektif.

Selain itu, administrasi pendidikan mengarah kepada pengelolaan edukasi untuk mewujudkan ekuilibrium hidup peserta didik, meningkatkan keimanan dan ketakwaan serta akhlak mulia.

Administrasi penddikan merupakan aktivitas bersama yang diselenggarakan oleh sekelompok masyarakat dan terlibat dalam tugas-tugas edukasi serta harus dijalankan oleh para pendidik menuju pada tujuan yang telah ditetapkan

Kegiatan pendidikan juga diselenggarakan melalui penggunaan mekanisme administrasi untuk mengontrol serangkaian kegiatan pendidikan yang diarahkan untuk mencapai tujuan pendidikan dengan bekerjasama kelompok. Oleh karena itu, administrasi pendidikan bukan hanya kegiatan pendidikan, melainkan kegiatan pengelolaan yang menjamin terselenggaranya rangkaian kegiatan pendidikan seefisien dan seefektif mungkin untuk mencapai tujuan yang telah ditentukan. Selain kegiatan administrasi pendidikan, pimpinan madrasah yang melaksanakan supervise akademik menjadi hal yang penting bagi seorang pendidik dan merupakan hal yang wajib menjadi perhatian bagi keberlangsungan kualitas pembelajaran di Madrasah. 
Menurut Masaong (2013), supervisi adalah upaya memberikan rangsangan, mengkoordinasi dan memberikan bimbingan terhadap perkembangan para pendidik di madrasah, baik secara perseorangan maupun secara komunal disertai solidaritas serta perilaku-perilaku mengajar yang efektif sehingga peserta didik mampu bekerjasama secara aktif dalam komunitas demokratis melalui rangsangan serta bimbingan dari para pendidik.

Adapun pengertian lain dari supervise merupakan usaha yang dilakukan oleh para pendidik untuk menfasilitasi serta membantu para peserta didik menjalani proses pembelajaran yang lebih baik dan efektif dibandingkan proses pembelajaran yang dilalui sebelumnya. Supervisi merupakan promotor perubahan manusia ke arah yang lebih baik melalui program terencana dengan teliti.

Supervisi bertujuan untuk mempelajari serta mengkoreksi secara kolektif dalam membimbing dan mengarahkan perkembangan peserta didik melalui teknis pelayanan yang professional serta mampu mengembangkan kondisi pembelajaran yang efektif. Supervisi ialah suatu aktivitas yang dilaksanakan untuk membantu para tenaga pendidik dalam menjalankan pekerjaan mereka menjadi lebih baik. (Rosmiaty Azis:2016).

Administrasi pendidikan dan supervisi akademik adalah dua hal penting yang akan member pengaruh terhadap kinerja seorang guru dalam melaksanakan PBM di Madrasah. Ketika seorang guru sudah memiliki administrasi pendidikan yang baik dan didukung oleh kegiatan supervisi yang dilakukan oleh kepala madrasah, maka diharapkan kinerja guru akan semakin meningkat.

Dengan demikian, kinerja guru merupakan hasil yang dicapai guru dalam melaksanakan tugas-tugas yang berada dalam ranahnya sebagai pendidik dan guru untuk mencapai hasil belajar lulusan/siswa yang optimal. Prestasi guru yang baik tentunya tercermin dari penampilannya, baik dari segi kemampuan akademik maupun kemampuan profesionalnya menjadi seorang guru yang berarti mampu mengatasi mengajar di kelas dan mendidik siswa dengan sebaik-baiknya di luar kelas. Guru memanifestasikan dirinya dalam kegiatan dan tugas belajar mengajar. Tugas guru di lembaga pendidikan merupakan salah satu bentuk aktivitas guru. Jika kinerja guru meningkat maka kualitas hasilnya akan meningkat pula.

Kenyataan di lapangan memberikan petunjuk tentang gambaran kinerja guru yang mengajar dan mendidik pada MAN 1 BintanKepulauan Riau, bahwa ada beberapa dimensi atau aspek yang turut menentukan perkembangan kinerja guru tersebut, antara lain: (1) Kondisi implementasi administrasi pendidikan yang diselenggarakan oleh kepala madrasah pada beberapa aspek yaitu ketatausahaan, siswa, guru, sarana prasarana termasuk pengawasan dan supervisi serta kelanjutan produk supervisi belum maksimal dilakukan oleh kepala madrasah, masih ditemukan system administrasi yang belum lengkap, dikerjakan oleh masing-masing personil yang diberi tugas oleh kepala madrasah bekerja apa adanya, belum totalitas dalam menyajikan data administrasi yang lengkap, (2) kemampuan yang dimiliki kepala madrasah MAN 1 BintanKepulauan Riau dalam mengelola proses pembelajaran selama ini masih perlu lagi ditingkatkan terutama pada pada aspek kerjasama atau team work dalam menyelesaikan suatu masalah atau kegiatan yang melibatkan orang banyak guru dan guru. Di sisi lain, kemampuan kepala madrasah dalam melakukan supervisi akademik yang belum optimal terutama frekuensi dan hasil output serta umpan balik yang diterima guru, agar dapat memahami dan kendala yang dihadapi guru tersebut dalam peningkatkan kinerja dalam mengajar guru 
tersebut, (3) pemberian dorongan dan spirit atau motivasi guru yang dilakukan kepala madrasah masih perlu ditingkatkan lagi, masih ditemukan kepala madrasah belum sepenuhnya memberikan ruang dan dedikasi untuk guru berkreasi dan berinoavsi untuk menemukan model dan desain pembelajaran yang lebih unggul dan kekinian, (4) ada kesan guru dalam melaksanakan tugas pokok dan fungsinya serta kewenangan yang diberikan berjalan secara alamiah saja, artinya kondisi kegiatan belajar mengajar stagnan, tidak perlu dilakukan perubahan yang inovatif dan kreatif dari keadaan sebelumnya, sehingga guru dalam kinerjanya hanya sesuai uraian tugasnya, tidak ada yang pembaharuan yang bisa dilakukan oleh guru terutama dalam proses pembelajaran.

Berdasar pada uraian diatas maka penelitian ini disusun melalui konsep kerangka konseptual yang dapat digambarkan dalam kerangka konseptual sebagai berikut :

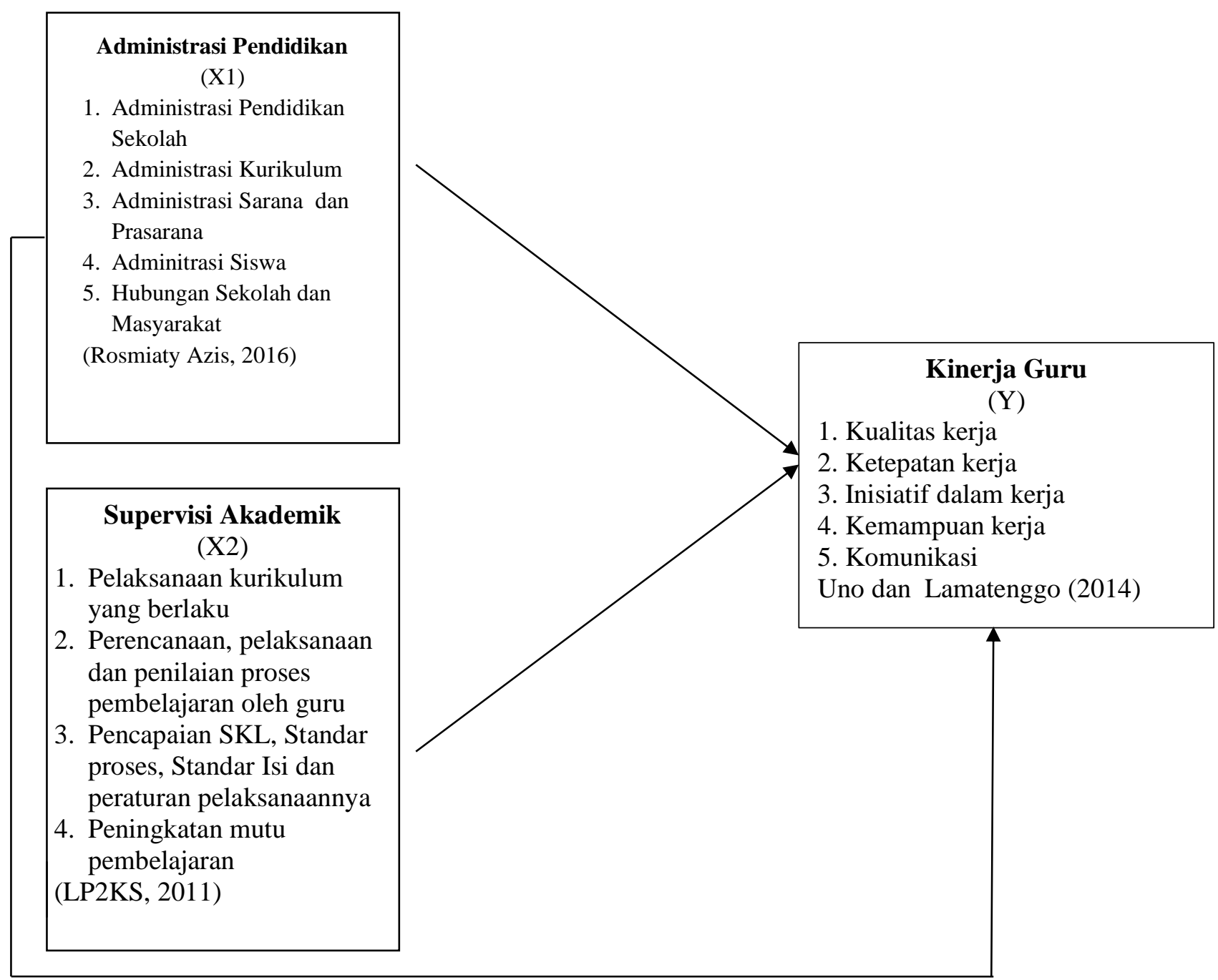

Gambar 1. Kerangka Konseptual

Berdasarkan kerangka konseptual Sebagai hasil dari kerangka konseptual yang diuraikan di atas, penelitian ini akan mengembangkan hipotesis berikut: 
Terdapat pengaruh positif dan signifikan administrasi pendidikan terhadap kinerja guru pada MAN 1 BintanKepulauan Riau.

1. Terdapat pengaruh positif dan signifikan supervisi akademik terhadap kinerja guru pada MAN 1 Bintan Kepulauan Riau.

2. Terdapat pengaruh positif dan signifikan administrasi pendidikan dan supervisi akademik terhadap kinerja guru pada MAN 1 BintanKepulauan Riau

\section{KAJIAN PUSTAKA}

\section{Administrasi Pendidikan}

Pengertian administrasi pendidikan adalah ilmu yang menjelaskan tentang pengelolaan sumber daya manusia termasuk didalamnya kurikulum dan fasilitas, terciptanya situasi dan kondisi yang nyaman serta menyenangkan dalam rangka mewujudkan fungsi edukasi secara maksimal dan efektif. (Engkoswara dalam Rosmiaty, 2016:2).

Hadari Nawawi dalam Rosmiaty (2016:2) mengatakan, administrasi pendidikan adalah keseluruhan proses atau rangkaian kegiatan pengelolaan upaya kerjasama sekelompok orang untuk mewujudkan fungsi edukasi secara terukur yang di laksanakan dalam kawasan khusus, apalagi dalam institusi pendidikan yang formal. Kemudian dijelaskan pula perbedaan antara kegiatan operasional pendidikan dengan administrasi pendidikan. Aktivitas operasional pendidikan adalah kegiatan teknis pendidikan, seperti aktivitas belajar mengajar, bimbingan dan konseling, dan lain sebagainya., Sedangkan administrasi pendidikan berurusan dengan pengendalian operasi agar dikoordinasikan dan diarahkan untuk mencapai tujuan pendidikan. Pendidikan akan berusaha untuk efisiensi dan efektivitas dalam mengejar tujuan yang telah ditetapkan.

Lebih lanjut dijelaskan mengenai proses adminsitrasi edukasi yang merupakan upaya pencapaian tujuan edukasi yang terpadu, berkelompok dan terkoordinir dengan maksimal untuk menjamin agar bahan yang dibutuhkan dapat dipergunakan dengan tepat dan efektif.

Keterbatasan-keterbatasan yang diuraikan di atas mengisyaratkan bahwa administrasi pendidikan merupakan suatu upaya untuk mengkoordinasikan perilaku manusia dalam pendidikan, agar semua sumber daya dikelola seefisien mungkin, sehingga tujuan pendidikan dapat tercapai.

\section{Supervisi Akademik}

Menurut Masaong (2013), supervisi adalah upaya memberikan rangsangan, mengkoordinasi dan memberikan bimbingan terhadap perkembangan para pendidik di madrasah, baik secara perseorangan maupun secara komunal disertai solidaritas serta perilaku-perilaku mengajar yang efektif sehingga peserta didik mampu bekerjasama secara aktif dalam komunitas demokratis melalui rangsangan serta bimbingan dari para pendidik.

Tujuan yang ingin dicapai dari pada umumnya supervisi adalah untuk pendidik dan staf lain di madrasah, sehingga digunakan untuk meningkatkan kualitas kerja mereka. Sebagai hasil dari pembinaan dan peningkatan profesi guru, pembahasan ini ditujukan untuk memperbaiki proses belajar mengajar di kalangan guru.

\section{Kinerja Guru}


Tenaga pendidik dalam hal ini, mengandung komponen yang sangat penting. Selain itu, ia juga mengandung sejumlah komponen penting lainnya. Guru adalah setiap orang yang memiliki kewenangan serta bertanggungjawab terhadap edukasi siswa, baik secara perseorangan maupun kelompok baik di lingkungan sekolah maupun di lingkungan eksternal sekolah (Syaiful Bahri Djamarah, 2010:26). Dengan demikian kinerja pendidik adalah kemampuan yang ditunjukkan oleh guru dalam melaksanakan tugas atau pekerjaannya (Tutik Rachmawati dan Daryanto, 2013:16). Artinya, adanya kinerja guru yang baik maka proses pembelajaran akan menjadi maksimal. Wahyudi (2012: 86) menyatakan bahwa kinerja guru merupakan hasil yang dicapai guru dalam melaksanakan tugas yang diberikan berdasarkan keterampilan, pengalaman, kejujuran dan penggunaan waktu. Baik atau tidaknya kinerja seorang guru / tenaga pendidik sangat dipengaruhi oleh kesesuaian tujuan yang telah ditetapkan dengan aktivitas pendidikan yang telah dilaksanakan. Selain itu, kinerja guru dan pendidik yang baik secara tidak langsung berkontribusi pada pendidikan yang efektif, sebagaimana dikemukakan oleh Husdart dalam Supardi (2013: 55), maka bahwa prestasi akademik pendidik akan mempengaruhi peningkatan kedisiplinan, karakter, sikap dan capaian studi peserta didik demi tercapainya proses pendidikan yang efektif.

Berdasarkan defenisi kinerja tenaga pendidikdi atas dapat diketahui bahwa kinerja guru merupakan kemampuan atau kompetensi yang dimiliki seseorang guru dalam proses belajar mengajar harus dilaksanakan untuk mencapai hasil belajar yang diinginkan. Selanjutnya, kinerja guru akan membantu suatu lembaga pendidikan meningkatkan kualitas pendidikannya.

Berdasarkan Abdul Rahman Abdi, 2020. Pengaruh Administrasi Pendidikan, Pengawasan Terhadap Mutu Proses Belajar Mengajar di Raudhatul Atfhal (RA) Kab. Gowa. Hasil penelitian menunjukkan ada pengaruh yang positif dan signifikan antara administrasi pendidikan terhadap mutu proses belajar mengajar di RA Kab. Gowa. Margi Purbasari, 2015 melakukan penelitian terhadap "Pengaruh Supervisi Akademik terhadap Kinerja Guru dalam Pembelajaran di Sekolah Dasar Daerah Binaan I Kecamatan Pengadegan Kabupaten Purbalingga”. Berdasarkan uji hasil Variabel supervisi akademik memiliki pengaruh sebesar 23,2\% terhadap kinerja guru dalam pembelajaran ketika digunakan hubungan sedang, artinya variabel kinerja guru mampu dijelaskan oleh variabel supervisi akademik sebesar 23,2\% melalui hubungan linier $\hat{Y}=75,977+0,4 \mathrm{X}$

\section{METODE PENELITIAN}

Pendekatan penelitian sebagai cara berpikir yang diadopsi peneliti tentang bagaimana desain penelitian dibuat dan penelitian akan dilakukan. Adapun pendekatan penelitian yang digunakan dalam penelitian ini adalah pendekatan kuantitatif. Dalam hal ini, akan diuji hipotesis penelitian tentang seberapa besar pengaruh administrasi pendidikan dan supervisi akademik terhadap kinerja guru pada MAN 1 Bintan Kepulauan Riau. Menurut Sugiyono (1997: 57) Populasi adalah wilayah generalisasi yang terdiri atas obyek atau subyek yang mempunyai kuantitas dan karakteristik tertentu yang ditetapkan oleh peneliti untuk dipelajari dan kemudian ditarik kesimpulannya. Adapun populasi penelitian ini adalah seluruh guru MAN 1 BintanKepulauan Riau sebanyak 30 orang yang mengajar pada berbagai jenjang kelas yang berbeda. Teknik pengambilan sampel dari jumlah populasi yang ada, yaitu sampel guru-guru diambil dengan teknik sampel total. Artinya semua populasi yang ada dalam penelitian ini 
bertindak sebagai sampel penelitian, sehingga sampel penelitian sebanyak 30 orang. Teknik analisis data yang digunakan adalah teknik analisis regresi linier berganda yang didahului dengan uji validitas dan uji reliabiitas data. Penelitian uji hipotesis digunakan uji $t$ untuk menguji hubungan secara parsial (sendiri-sendiri) dan uji $\mathrm{F}$ untuk mengetahui hubungan secara simultan (bersama-sama). Analisis kebermaknaan dalam penelitian ini digunakan melalui uji koefisien determinasi ( $\mathrm{R}$ square). Persamaan analisis regresi digunakan untuk mengetahui adanya pengaruh masing-masing variabel terikat terhadap variabel bebas. Adapun variabel bebas yang terdiri atas (1) administrasi pendidikan, (2) supervisi akademik, sedangkan variabel terikat yaitu kinerja guru. Melalui program SPSS versi 25 dapat diketahui hasil perhitungan analisis regeresi linier berganda tersebut. Rumus regresi linier berganda, yaitu:

$$
\mathrm{Y}=\alpha+\beta_{1} \mathrm{X}_{1}+\beta_{2} \mathrm{X}_{2}+\mathrm{e}
$$

Keterangan:

$\mathrm{Y}=$ Kinerja Guru

$\mathrm{X}_{1}=$ Administrasi Pendidikan

$\mathrm{X}_{2}=$ Supervisi Akademik

$\alpha=$ Konstanta.

$\beta 1=$ Koefisien estimate administrasi pendidikan

$\beta 2=$ Koefisien estimate supervisi akademik

Berdasarkan hasil olah data menggunakan SPSS versi 25 diperoleh nilai coefisien konstanta sebesar 13,816, koefisien administrasi pendidikan 0,053, koefisien supervisi akademik 0,571, maka persamaan regresi dapat dirumuskan sebagai berikut:

$$
\mathrm{Y}=13,816+0,053 \mathrm{X}_{1}+0,571 \mathrm{X}_{2}+\mathrm{e}
$$

\begin{tabular}{|c|c|c|c|c|c|c|c|c|}
\hline \multicolumn{9}{|c|}{$\begin{array}{c}\text { Tabel 1. } \\
\text { hasil uji t } \\
\text { Coefficients }^{\mathrm{a}}\end{array}$} \\
\hline \multirow[b]{2}{*}{ Model } & & \multicolumn{2}{|c|}{$\begin{array}{l}\text { Unstandardized } \\
\text { Coefficients }\end{array}$} & \multirow{2}{*}{$\begin{array}{c}\text { Standardized } \\
\text { Coefficients } \\
\text { Beta }\end{array}$} & \multirow[b]{2}{*}{$\mathrm{t}$} & \multirow[b]{2}{*}{ Sig. } & \multicolumn{2}{|c|}{ Collinearity Statistics } \\
\hline & & $\mathrm{B}$ & Std. Error & & & & Tolerance & VIF \\
\hline 1 & (Constant) & 13.816 & 6.180 & & 2.235 & .034 & & \\
\hline & $\begin{array}{l}\text { ADMINISTRASI } \\
\text { _PENDIDIKAN }\end{array}$ & .053 & .206 & .072 & .258 & .798 & .223 & 4.479 \\
\hline & $\begin{array}{l}\text { SUPERVISI_AK } \\
\text { ADEMIK }\end{array}$ & .571 & .238 & .667 & 2.397 & .024 & .223 & 4.479 \\
\hline
\end{tabular}

\section{HASIL PENELITIAN}

1. Berdasarkan tabel uji $t$ diketahui bahwa nilai $t_{\text {hitung }}$ variabel administrasi pendidikan $\left(\mathrm{X}_{1}\right)$ sebesar 0,258 kurang dari 1,99 $\left(\mathrm{t}_{\text {hitung }}<\mathrm{t}_{\text {tabel }}\right)$ maka $\mathrm{H}_{0}$ diterima dan $\mathrm{H}_{1}$ ditolak, artinya administrasi pendidikan secara parsial tidak berpengaruh terhadap kinerja tenaga pendidik / guru.

2. Berdasarkan tabel uji t diketahui bahwa nilai $t_{\text {hitung variabel supervisi akademik }}$ $\left(\mathrm{X}_{2}\right)$ sebesar 2,397 lebih dari 1,99 ( $\mathrm{t}_{\text {hitung }}>\mathrm{t}_{\text {tabel }}$ ) maka $\mathrm{H}_{0}$ ditolak dan $\mathrm{H}_{1}$ diterima, artinya supervisi akademik secara parsial berpengaruh terhadap kinerja guru. 


\section{AkMen \\ Volume 18 Nomor 2 Agustus 2021 \\ Hal. 198 - 208 \\ e-ISSN : 2621-4377 \& p-ISSN : 1829-8524 \\ Hbmepage: https//e-jurnal.nobel.acid/indexphp/akmen}

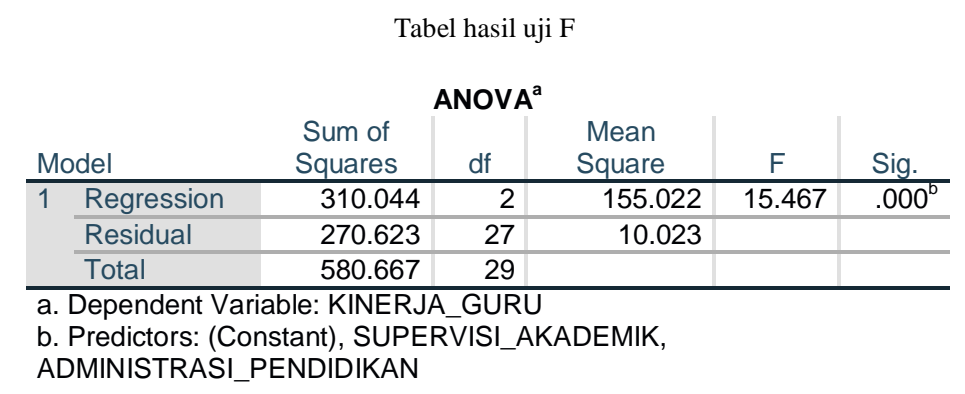

3. Dari hasil uji $\mathrm{F}$ diperoleh nilai $\mathrm{F}_{\text {hitung }}$ sebesar 15,467 dan jika dibandingkan dengan nilai $\mathrm{F}_{\text {tabel }}$ dengan taraf signifikansi $(\alpha)=5 \%$, maka nilai $\mathrm{F}_{\text {tabel }}=2,73$, (artinya $\mathrm{F}_{\text {hitung }}>\mathrm{F}_{\text {tabel }}(15,467>2,73)$ sehingga dapat dikatakan bahwa $\mathrm{H}_{0}$ ditolak dan $\mathrm{H}_{1}$ diterima, dengan kata lain administrasi pendidikan dan supervisi akademik secara bersama-sama berpengaruh terhadap kinerja guru.

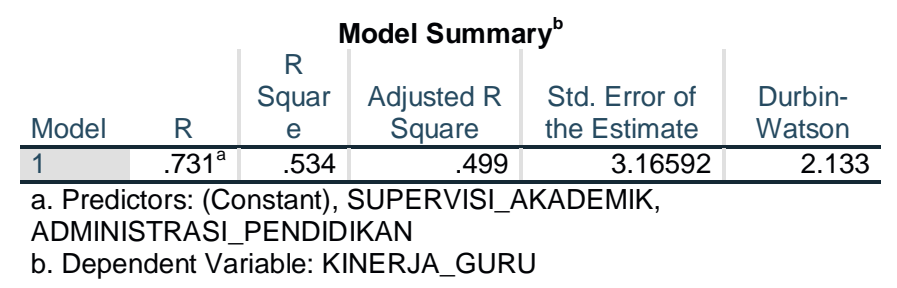

4. Berdasarkan uji koefisien determinasi diperoleh koefisien determinasi $\left(\mathrm{R}^{2}\right)$ sebesar 0,534 atau (53,4 \%). Hal ini menunjukkan bahwa 53,4\% kinerja guru dipengaruhi oleh administrasi pendidikan dan supervisi akademik. Sedangkan $46,6 \%$ dipengaruhi oleh variabel lain yang tidak dimasukkan dalam model penelitian ini.

\section{Pembahasan}

Dalam bagian ini akan dibahas pengaruh beberapa faktor yang mempengaruhi kinerja guru pada MAN 1 BintanKepulauan Riau. Pembahasan masing-masing variabel tersebut dikemukakan berikut ini:

\section{Pengaruh secara parsial administrasi pendidikan terhadap kinerja guru.}

Pengaruh administrasi pendidikan terhadap kinerja guru diperoleh $\mathrm{t}$ hitung 0,258 dengan signifikansi 0,798 menandakan bahwa administrasi pendidikan tidak mempunyai pengaruh positif dan signifikan terhadap kinerja guru (Y). Dengan demikian dapat disimpulkan bahwa Ho diterima dan $\mathrm{H} 1$ ditolak, sehingga hipotesis yang menyatakan dugaan adanya pengaruh positif dan signifikan antara administrasi pendidikan terhadap kinerja guru pada MAN 1 BintanKepulauan Riau tidak dapat diterima.

Administrasi pendidikan merupakan seperangkat administrasi yang disiapkan oleh satuan pendidikan dalam rangka memenuhi kebutuhan pencapaian delapan standar nasional pendidikan. Pentingnya keberadaan administrasi pendidikan yang dalam hal ini harus dimiliki oleh seorang kepala Madrasah khususnya di MAN 1 BintanKepulauan 
Riau merupakan hal yang harus menjadi suatu kebutuhan mendasar untuk memenuhi visi misi dan tujuan madrasah baik dalam jangka pendek, menengah dan panjang.

Hasil penelitian ini berbeda dengan penelitian terdahulu yang dilakukan oleh Abdul Rahman Abdi (2020) yang menyatakan bahwa ada pengaruh yang positif dan signifikan antara administrasi pendidikan terhadap kinerja guru.

Dari hasil penelitian yang menunjukkan bahwa tidak ada pengaruh administrasi pendidikan terhadap kinerja guru membuktikan bahwa pengelolaan administrasi pendidikan masih perlu diperbaiki khususnya menyangkut tentang pemenuhan tugas guru dalam melengkapi segala perangkat adminitrasi pembelajarannya sehingga memberi dampak yang positif terhadap peningkatan kinerja guru di MAN 1 BintanKepulauan Riau.

\section{Pengaruh secara parsial supervisi akademik terhadap kinerja guru.}

Supervisi atau Pengawasan bagian serangkaian kegiatan pembinaan untuk membantu tenaga pendidik dan tenaga pendidikan lainnya dalam memperbaiki cara, bahan, dan evaluasi pengajaran dengan melakukan dorongan, komunikasi dan arahan secara kontinyu agar tenaga pendidik menjadi lebih profesional dalam meningkatkan pencapaian tujuan sekolah.

Supervisi yang menekankan pada pengembangan guru, pengembangan profesional guru lebih ditujukan pada upaya peningkatan dan peningkatan kemampuan profesional guru. Hal ini sering disebut dengan supervisi akademik. Supervisi atau pengawasan yang menitikberatkan pada pembinaan direksi madrasah, pembinaan direksi madrasah bertujuan untuk meningkatkan kinerja manajemen madrasah agar berkualitas. Ini sering disebut pengendalian manajemen.

Pengaruh supervisi akademik terhadap kinerja guru diperoleh t hitung 2,397 dengan signifikansi 0,024 menandakan bahwa supervisi akademik mempunyai pengaruh positif dan signifikan terhadap kinerja guru (Y). dengan demikian dapat disimpulkan bahwa Ho ditolak dan $\mathrm{H} 1$ diterima, sehingga hipotesis yang menyatakan dugaan adanya pengaruh positif dan signifikan antara supervisi akademik terhadap kinerja guru pada MAN 1 BintanKepulauan Riau dapat diterima.

Pentingnya dilakukan supervisi akademik secara berkala oleh kepala madrasah dan pengawas bina di Kementerian Agama Kepulauan Riau untuk melihat secara langsung kinerja guru yang bersangkutan. supervisi yang dilakukan oleh kepala madrasah dan pengawas adalah bantuan dan bimbingan profesional bagi guru dalam melaksanakan tugas pedagogik dalam rangka peningkatan pembelajaran dan pengajaran dengan senantiasa merangsang, mengkoordinasikan dan membimbing serta meningkatkan kinerja guru secara individu maupun kelompok.

\section{Pengaruh Secara Simultan Variabel Adminitrasi Pendidikan dan Supervisi Akademik terhadap Kinerja Guru}

Berdasarkan hasil analisis didapatkan nilai F statistik sebesar 15,467 dengan nilai signifikansi 0,000 lebih kecil dari 0,05, maka dapat diketahui bahwa secara simultan ada pengaruh signifikan antara administrasi pendidikan dan supervisi akademik terhadap kinerja guru pada MAN 1 BintanKepulauan Riau. Demikian pula berdasarkan uji koefisien determinasi diperoleh koefisien determinasi $\left(\mathrm{R}^{2}\right)$ sebesar 0,534 atau $(53,4 \%)$. Hal ini menunjukkan bahwa 53,4\% kinerja guru dipengaruhi oleh administrasi 
pendidikan dan supervisi akademik. Sedangkan 46,6\% dipengaruhi oleh variabel lain yang tidak dimasukkan dalam model penelitian ini.

\section{SIMPULAN}

Berdasarkan hasil penelitian dan pembahasan yang telah dikemukakan di atas dapat ditarik beberapa kesimpulan sebagai berikut :

1. Secara parsial adminitrasi pendidikan $(\operatorname{sig} 0,798>\alpha 0,05)$ tidak berpengaruh secara positif dan signifikan terhadap kinerja guru pada MAN 1 BintanKepulauan Riau. Ini berarti bahwa administrasi pendidikan harus ditingkatkan dalam rangka menciptakan kinerja guru yang profesional guna mencapai kualitas pendidikan yang lebih baik.

2. Secara parsial supervisi akademik (sig $0,024<\alpha$ 0,05) berpengaruh positif dan signifikan terhadap kinerja guru pada MAN 1 BintanKepulauan Riau. Hal ini berarti bahwa supervisi akademik yang dilakukan oleh kepala madrasah sudah memberikan konstribusi yang positif terhadap kinerja guru.

3. Secara simultan menujukkan administrasi pendidikan $\left(\mathrm{X}_{1}\right)$ dan supervisi akademik $\left(\mathrm{X}_{2}\right)$ berpengaruh secara positif dan signifikan terhadap kinerja guru (Y) pada MAN 1 BintanKepulauan Riau. Hal ini berarti bahwa peningkatan administrasi pendidikan dan supervisi akademik mempengaruhi kinerja guru sebesar 53,4\% Sedangkan 46,6\% dipengaruhi oleh variabel lain yang tidak dimasukkan dalam model penelitian ini.

\section{SARAN}

Dari simpulan yang diperoleh, maka diberikan saran dan rekomendasi sebagai berikut:

1. Pihak Kepala MAN 1 BintanKepulauan Riau agar selalu melakukan pengawasan secara berkelanjutan dalam pelaksanaan administrasi pendidikan oleh guru - guru sehingga diharapkan dapat memberikan peningkatan kinerja guru dalam rangka mencapai visi, misi dan tujuan madrasah.

2. Pihak pengawas bina di MAN 1 BintanKepulauan Riau agar memantau penyelenggaraan supervisi pendidikan yang diselenggarakan bersama dengan pimpinan madrasah guna tercapainya kinerja guru yang optimal.

3. Diperlukan adanya penelitian selanjutnya untuk melihat variabel - variabel lain yang bisa mempengaruhi kinerja guru khususnya di MAN 1 Bintan Kepulauan Riau.

\section{DAFTAR PUSTAKA}

Asf, Jasmani, 2013. Supervisi Pendidikan (terobosan baru dalam peningkatan kinerja pengawas sekolah dan guru. Jogjakarta: Ar-ruzz media.

Burhanuddin, Yusak. 2015. Administarsi Pendidikan, Bandung: Pustaka Setia

Daryanto. 2011. Administrasi pendidikan. Jakarta: Rineka cipta. 
Depdiknas. 2007. Standar Isi Untuk Satuan Pendidikan Dasar dan Menengah. Jakarta: Dirjen Dikti Depdiknas

Engkoswara, 2011. Administrasi Pendidikan, Bandung: Akfabeta

Hamzah B Uno dan Nana Lamatenggo. 2014. Teori Kinerja dan Pengukurannya, Jakarta : PT. Bumi Aksara

Masaong, Abd. Kadim. 2013. Supervisi Pembelajaran dan Pengembangan Kapasitas Guru. Jakarta: Alfabeta.

Rosmiaty Azis, 2016. Pengantar Administrasi Pendidikan. Penerbit Sibuku:Bantu Yogyakarta

Sugiyono. 2016. Metode Penelitian Pendidikan. Bandung: Alfabeta Bandung.

Supardi. 2013. Kinerja guru. Jakarta: PT Raja Grafindo Persada.

Tutik Rachmawati dan Daryanto. 2013. Penilaian Kinerja Profesi Guru dan Angka Kreditnya, Yogyakarta : Gava Media

Syaiful Bahri Djamarah. 2010. Guru dan Anak Didik Dalam Interaksi Edukatif, Jakarta : PT Rineka Cipta

Wahyudi, Imam. 2012. Mengejar profesionalisme guru. Jakarta: $\quad$ Prestasi Pustaka 